\title{
Low temperature limits photoperiod control of smolting in Atlantic salmon through endocrine mechanisms
}

\author{
STEPHEN D. MCCORMICK, ${ }^{1}$ SHUNSUKE MORIYAMA, ${ }^{2}$ AND B. THRANDUR BJ ÖRNSSON ${ }^{3}$ \\ ${ }^{1}$ Conte Anadromous Fish Research Center, Biological Resources Division, US Geological Survey, \\ Turners Falls, Massachusetts 01376; 'Laboratory of Molecular Endocrinology, \\ School of Fisheries, Kitasato University, Sanriku, I wate, J apan; and ${ }^{3} \mathrm{Fish}$ Endocrinology \\ Laboratory, Department of Zool ogy, Göteborg U niversity, Göteborg, Sweden
}

\begin{abstract}
McCormick, Stephen D., Shunsuke Moriyama, and B. Thrandur Björnsson. Low temperature limits photoperiod control of smolting in Atlantic salmon through endocrine mechanisms. Am J Physiol Regulatory Integrative Comp Physiol 278: R1352-R1361, 2000.-We have examined the interaction of photoperiod and temperature in regulating the parr-smolt transformation and its endocrine control. Atlantic salmon juveniles were reared at a constant temperature of $10^{\circ} \mathrm{C}$ or ambient temperature $\left(2^{\circ} \mathrm{C}\right.$ from J anuary to April followed by seasonal increase) under simulated natural day length. At $10^{\circ} \mathrm{C}$, an increase in day length [ $16 \mathrm{~h}$ of light and 8 h of darkness (LD 16:8)] in F ebruary accelerated increases in gill $\mathrm{Na}^{+}-\mathrm{K}^{+}$-ATPase activity, whereas fish at ambient temperature did not respond to increased day length. I ncreases in gill $\mathrm{Na}^{+}-\mathrm{K}^{+}$-ATPase activity under both photoperiods occurred later at ambient temperature than at $10^{\circ} \mathrm{C}$. Plasma growth hormone $(\mathrm{GH})$, insulin-like growth factor, and thyroxine increased within 7 days of increased day length at $10^{\circ} \mathrm{C}$ and remained elevated for 5-9 wk; the same photoperiod treatment at $2{ }^{\circ} \mathrm{C}$ resulted in much smaller increases of shorter duration. Plasma cortisol increased transiently 3 and 5 wk after LD $16: 8$ at $10^{\circ} \mathrm{C}$ and ambient temperature, respectively. Plasma thyroxine was consistently higher at ambient temperature than at $10^{\circ} \mathrm{C}$. Plasma triiodothyronine was initially higher at $10^{\circ} \mathrm{C}$ than at ambient temperature, and there was no response to LD 16:8 under either temperature regimen. There was a strong correlation between gill $\mathrm{Na}^{+}-\mathrm{K}^{+}-$-ATPase activity and plasma $\mathrm{GH}$; correlations were weaker with other hormones. The results provide evidence that low temperature limits the physiological response to increased day length and that $\mathrm{GH}$, insulin-like growth factor I, cortisol, and thyroid hormones mediate the environmental control of the parrsmolt transformation.
\end{abstract}

growth hormone; insulin-like growth factor I; cortisol; thyroxine; osmoregulation; sodium-potassium-adenosinetriphosphatase; fish; anadromous; rhythm; devel opment

PHOTOPERIODIC REGULATION of seasonal changes in physiology is a well-known phenomenon in vertebrates and is generally thought to be the result of entrainment of an endogenous circannual rhythm by the annual photocycle (17). Circadian rhythms exhibit temperature compensation, such that the free-running period is largely

\footnotetext{
The costs of publication of this article were defrayed in part by the payment of page charges. The article must therefore be hereby marked "advertisement" in accordance with 18 U.S.C. Section 1734 solely to indicate this fact.
}

independent of temperature within the physiological range (47). In contrast, the potential influence of temperature on circannual rhythms and their entrainment by photoperiod is not well characterized. This interaction is especially interesting for ectothermic vertebrates, which can experience a wide range of body temperatures (up to $40^{\circ} \mathrm{C}$ ) during the year. In these vertebrates, temperature may limit the rate of physiological changes (including signaling pathways) and has the potential to act as a cue or zeitgeber for seasonal changes.

The parr-smolt transformation (smolting) is a preparatory physiological adaptation that occurs in spring in Atlantic and Pacific salmon (18). Changes in salinity tolerance, visual pigments, buoyancy, metabolism, morphology, and behavior precede and are adaptive for downstream migration and seawater entry. Osmoregulation has been the most widely studied physiological change during smolting. I ncreased gill $\mathrm{Na}^{+}-\mathrm{K}^{+}$-ATPase activity and differentiation of chloride cells result in greater salt secretory capacity and increased salinity tolerance of smolts (34). Morphological changes during smolting include silvering, darkened fin margins, and decreased condition factor (weight-to-length ratio). Many of the physiological and morphological changes that comprise smolting are known to be responsive to photoperiod, advanced by increased day length and/or delayed by short days (51). Temperature has al so been shown to affect the timing of smolting, although to a more limited degree than photoperiod (36).

The endocrine system is the primary signaling pathway between external zeitgebers, internal rhythms, and seasonal physiological responses (17). In contrast to metamorphic events that rely heavily on a single stimulatory endocrine pathway, smolting involves a number of interacting endocrine systems. Growth hormone $(G H)$, insulin-like growth factor I (IGF-I), cortisol, and thyroid hormones increase during smolting and stimulate various physiological changes that occur during smolting, whereas prolactin is generally inhibitory $(11,18)$. In most salmonids, plasma GH levels increase in spring as a result of increased day length (3). Thyroid hormones can also be affected by changes in photoperiod, although the responses are not al ways consistent and temperature effects are largely unexamined (20). Although seasonal changes in plasma cortisol have been demonstrated (49), there is only limited 
evidence for an effect of photoperiod on circulating cortisol $(6,19)$. Homologous assays for teleost IGF-I have only recently been established, and the response of IGF -I to environmental change in teleosts in general and smolts in particular has not been previously examined. Use of exogenous hormone treatments has demonstrated that GH, IGF-I, and cortisol interact to upregulate gill $\mathrm{Na}^{+}-\mathrm{K}^{+}-$ATPase activity and salinity tolerance (29). Thyroid hormones may also be involved in the control of osmoregulation and other physiological changes during smolting (18).

The present study was undertaken to examine the interaction of photoperiod and temperature on the hormones that regulate smolting and the physiological changes that comprise smolting. Specifically, we examined the ability of increased day length to alter the timing of smolting at $10^{\circ} \mathrm{C}$ and $2^{\circ} \mathrm{C}$ (ambient temperature). Changes in gill $\mathrm{Na}^{+}-\mathrm{K}^{+}$-ATPase activity and condition factor were used to follow smolt devel opment, and the effect of environmental manipulation on circulating levels of GH, IGF-I, cortisol, and thyroid hormones was examined.

\section{METHODS}

Rearing and sampling of fish. Atlantic salmon (Salmo salar) were obtained as parr from the White River National Fish Hatchery (Bethel, VT) and brought to the Conte Anadromous Fish Research Center on 29 October, 8 mo after hatching. Rearing and experimental conditions are similar to those previously reported (31). Fish were randomly divided into four, isolated photoperiod rooms containing two 1-mdiameter tanks supplied with ambient river water at a flow rate of $4 \mathrm{l} / \mathrm{min}$ and supplemental aeration. Each tank contained $\sim 80$ fish. The fish were fed to satiation (Zeigler, Gardners, PA) by use of automatic feeders. Water was maintained at ambient temperature in all tanks until $7 \mathrm{~J}$ anuary, when two of the groups were supplemented with heated water to maintain a temperature of $9-10^{\circ} \mathrm{C}$ (Fig. 1). Fish at this time were $15.2-18.6 \mathrm{~cm}$ long and weighed $34.3-72.2 \mathrm{~g}$. I nitially, all groups were maintained on a simulated natural photoperiod [light-dark natural (LDN)] with seasonal increases in day length matching normal daylight hours. On 8 February, one group in each of the temperature regimens was subjected to an abrupt increase in day length to $16 \mathrm{~h}$ [16 hours of light and 8 hours of darkness (LD 16:8)]. Lighting was supplied by overhead fluorescent lights ( $500 \mathrm{Ix}$ at the water surface), and the LDN photoperiod was adjusted twice a week.

Feed was withheld for $24 \mathrm{~h}$ before sampling, which occurred from 1000 to 1100 Eastern Standard Time. Blood and gill samples were taken approximately every 2 wk from 5 J anuary through 19 May ( $n=10 /$ treatment). Fish were anesthetized (100 mg/l MS-222 neutralized to $\mathrm{pH} 7.0$ ), and fork length to the nearest millimeter and weight to the nearest $0.1 \mathrm{~g}$ were recorded. Blood was drawn from the caudal blood vessels into a 1-ml ammonium heparinized syringe and centrifuged at $8,000 \mathrm{~g}$ for $5 \mathrm{~min}$ at $4^{\circ} \mathrm{C}$. Plasma was al iquoted and stored at $-80^{\circ} \mathrm{C}$. Four to six gill filaments were severed above the septum, placed in $100 \mu$ l of ice-cold buffer containing (in mM) 150 sucrose, 10 EDTA, and 50 imidazole (pH 7.3), and frozen at $-80^{\circ} \mathrm{C}$ within $30 \mathrm{~min}$.

Measurement of gill $\mathrm{Na}^{+}-\mathrm{K}^{+}-$ATPase activity. $\mathrm{Na}^{+}-\mathrm{K}^{+}-$ ATPase activity was determined with a kinetic assay run in 96-well microplates at $25^{\circ} \mathrm{C}$ and read at a wavelength of 340 $\mathrm{nm}$ for $10 \mathrm{~min}$ (28). Gill tissue was homogenized in $125 \mu \mathrm{l}$ of buffer containing $150 \mathrm{mM}$ sucrose, $10 \mathrm{mM}$ EDTA, $50 \mathrm{mM}$ imidazole ( $\mathrm{pH} 7.3$ ), and $0.1 \%$ deoxycholic acid and centrifuged at $5,000 \mathrm{~g}$ for $30 \mathrm{~s}$. Ten-microliter samples were run in two sets of duplicates: one set contained assay mixture and the other assay mixture and $0.5 \mathrm{mM}$ ouabain. The resulting ouabain-sensitive ATPase activity measurement was expressed as micromoles of ADP per milligram of protein per hour. Protein concentration was determined using bicinchoninic acid protein assay (Pierce, Rockford, IL). Both assays are run on a THERMOmax microplate reader with use of SOFTmax software (Molecular Devices, Menlo Park, CA).

Hormone assays. Plasma cortisol levels were measured by a validated direct competitive enzyme immunoassay (8). The lower detection limit was $0.30 \mathrm{ng} / \mathrm{ml}$. With use of a pooled plasma sample, the average intra- and interassay variations were $5.5 \%(n=10)$ and $8.8 \%(n=10)$, respectively. Plasma $\mathrm{GH}$ levels were measured by an RIA validated for Atlantic salmon (5). The lower detection limit was $0.1 \mathrm{ng} / \mathrm{ml}$ with average intra- and interassay variations of $5.4 \%(n=9)$ and $3.9 \%(n=9)$, respectively. Plasma IGF-I was measured by homologous RIA (37). The lower detection limit was 0.20 $\mathrm{ng} / \mathrm{ml}$, with average intra- and interassay variations of $7 \%$ $(n=5)$ and $6.5 \%(n=5)$, respectively. Thyroxine $\left(T_{4}\right)$ and 3,5,3'-triiodo-L-thyronine $\left(T_{3}\right)$ concentrations were measured by a direct RI A (32). The lower detection limits were $0.5 \mathrm{ng} / \mathrm{ml}$ $\left(T_{4}\right)$ and $0.2 \mathrm{ng} / \mathrm{ml}\left(T_{3}\right)$. Intra- and interassay coefficients of variation for these assays were $4.3-11 \%$ and $3.2-5 \%$, respectively.

Calculati ons and statistics. Condition factor was calculated as follows: [weight/(length $\left.\left.{ }^{3}\right)\right] * 100$. A nonparametric threeway ANOVA on ranks was used to determine the significance of photoperiod, temperature, and changes over timeand their interaction. Nonparametric analysis was used because not all parameters were normally distributed. If photoperiod or temperature treatments were significant $(P<0.001)$, differences among treatments at each time point were tested using the nonparametric Kruskal-Wallis test. First- and secondorder polynomial regressions were calculated for all combinations of physiological variables. With one exception (plasma IGF-I vs. GH), $\mathrm{r}^{2}$ values for all significant regressions were greater for second- than for first-order polynomials; therefore, only second-order polynomial regressions are reported. To test the effect of treatment on these regression analyses, a covariateANOVA with "treatment" as a class variable (covariable) was conducted using SAS, general linear model procedure. To examine the relative explanatory power of endocrine parameters on gill $\mathrm{Na}^{+}-\mathrm{K}^{+}$-ATPase activity and condition factor, a best subsets regression analysis was used $(P<0.05)$. Endocrine parameters were logarithmically transformed for best subset regression analysis. Plasma $\mathrm{T}_{3}$-to- $\mathrm{T}_{4}$ ratio was not included in this analysis to prevent multiple colinearity with $\mathrm{T}_{4}$ and $\mathrm{T}_{3}$. Only sampling points after initiation of experimental treatments were used in statistical analyses. Thus the J anuary sampling point is presented graphically but is not included in statistical analyses.

\section{RESULTS}

Condition factor of the $10^{\circ} \mathrm{C}$-LDN group remained high until late March and declined steadily thereafter. A significant decrease in condition factor occurred within 1 wk of increased day length in the advanced photoperiod group (LD 16:8 in February) at $10^{\circ} \mathrm{C}$ and declined steadily until April (Fig. 1). Condition factor was significantly lower for the $10^{\circ} \mathrm{C}$-LD 16:8 group than for the $10^{\circ} \mathrm{C}$-LDN group from mid-F ebruary to midApril. Condition factor of both photoperiod groups was lower in February at ambient temperature than at $10^{\circ} \mathrm{C}$, remained at this level until late March, and 
Fig. 1. Top: seasonal change in day length and temperature of 4 experimental groups. Increased day length [16 $\mathrm{h}$ of light and $8 \mathrm{~h}$ of darkness (LD 16:8)] occurred on 8 February 8 (caret). Condition factor $\left[\right.$ [weight/(length $\left.\left.{ }^{3}\right)\right] \times$ 100; middle and gill $\mathrm{Na}^{+}-\mathrm{K}^{+}$-ATPase activity (bottom) in juvenileAtlantic salmon subjected to photoperiod and temperature treatments are shown. LDN, natural day length; AMB, ambient temperature. Values are means \pm SE $(n=12)$. Vertical lines unconnected to other lines indicate a significant difference from other groups at that time; points without vertical lines are not significantly different from one another $(P=0.05$, KruskalWallis test).
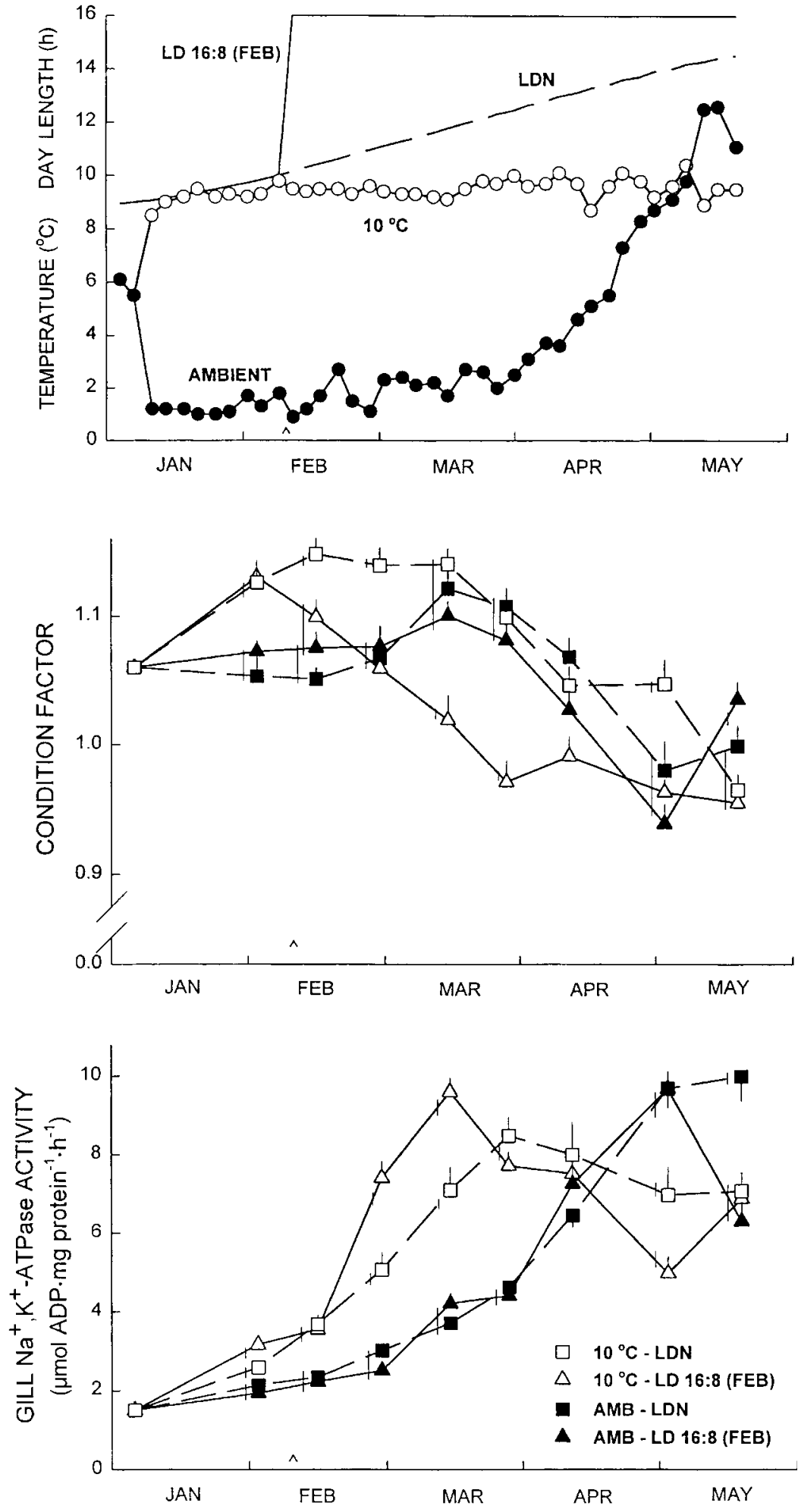

declined steadily thereafter. There were no significant differences between the two photoperiod treatments at ambient temperature until the last sampling in late May. Condition factor was significantly influenced by time, photoperiod, and interaction between temperature and photoperiod (3-way ANOVA, P < 0.001).

Gill $\mathrm{Na}^{+}-\mathrm{K}^{+}-$ATPase activity increased steadily from $\mathrm{J}$ anuary until late March in the $10^{\circ} \mathrm{C}-\mathrm{LDN}$ group (Fig.
1). In the $10^{\circ} \mathrm{C}$-LD $16: 8$ group, gill $\mathrm{Na}^{+}-\mathrm{K}^{+}$-ATPase activity rose abruptly $3 \mathrm{wk}$ after increased day length and remained significantly higher than in the $10^{\circ} \mathrm{C}$ LDN group throughout March. The $\mathrm{Na}^{+}-\mathrm{K}^{+}$-ATPase activity increased moreslowly in both ambient temperature groups than in the $10^{\circ} \mathrm{C}$ groups and reached peak levels in early May. There was no significant difference between the two photoperiod treatments at ambient 
temperature until late May, when there was a decrease in the LD 16:8 group. Gill Na+-K+-ATPase activity was significantly influenced by time, temperature, and temperature-photoperiod interaction $(P<0.02)$.

Plasma GH levels of the $10^{\circ} \mathrm{C}$-LDN group were low (1-2 $\mathrm{ng} / \mathrm{ml}$ ) from J anuary through late February and then increased steadily from mid-March to peak levels of $9.3 \mathrm{ng} / \mathrm{ml}$ in late May (Fig. 2). GH levels in the $10^{\circ} \mathrm{C}$-LD 16:8 group increased abruptly after 1 wk of increased day length and remained significantly higher than in the LDN group for 7 wk (mid-F ebruary to late March). Increased day length in the ambient tempera-
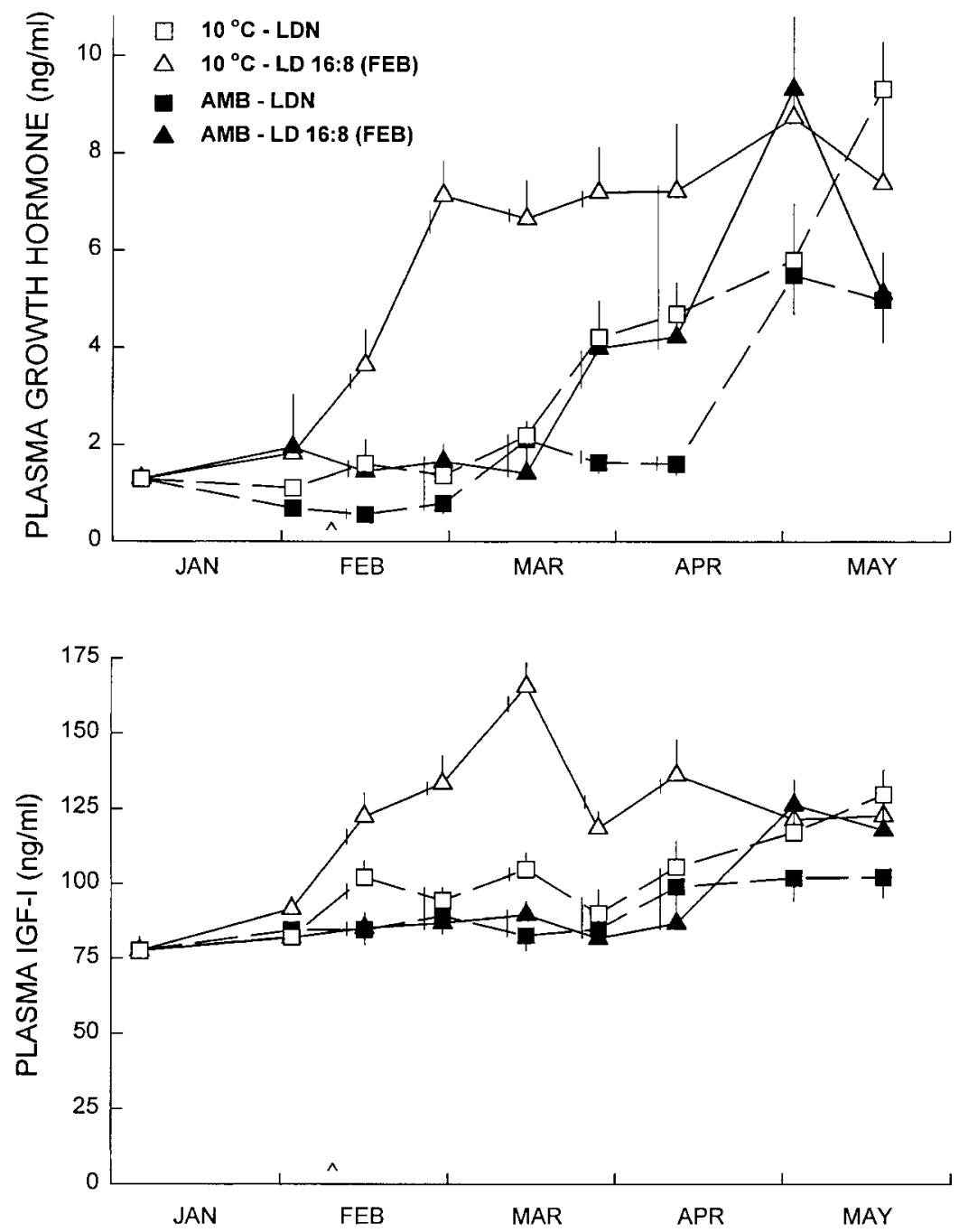

Fig. 2. Plasma growth hormone, insulin-like growth factor I (IGF-I), and cortisol in juvenileAtlantic salmon subjected to photoperiod and temperature treatments (see Fig. 1). Values are means \pm SE $(n=12)$. Increased day length in LD 16:8 groups occurred on 8 F ebruary (caret). Vertical lines unconnected to other lines indicate a significant difference from other groups at that time point; time points with no vertical lines are not significantly different from one another ( $P=0.05$, KruskalWallis test).

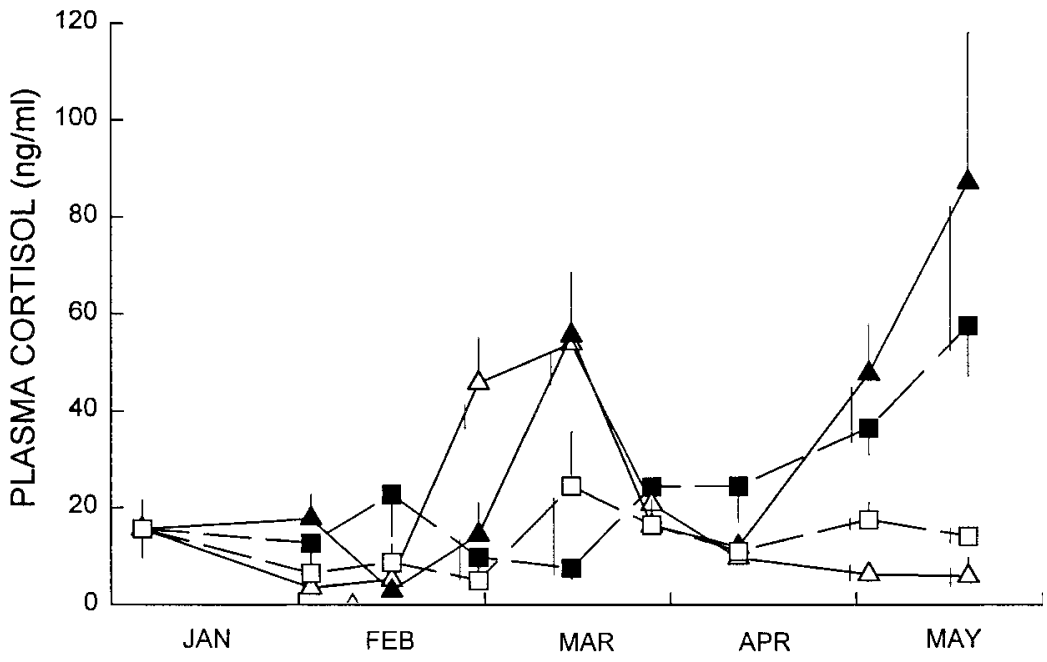


ture-LD 16:8 group had a more modest effect on plasma $\mathrm{GH}$. Plasma GH levels did not increase above $2 \mathrm{ng} / \mathrm{ml}$ until late March. In late March and early April, GH levels were significantly higher in the ambient temperature-LD 16:8 group than in the ambient temperatureLDN group. In general, ambient (low) temperatures resulted in later increases in plasma $\mathrm{GH}$, although peak levels were similar. Plasma GH was significantly influenced by time, temperature, photoperiod, and an interaction among the three $(P<0.001)$.

Plasma IGF-I levels increased modestly but steadily (from 75 to $125 \mathrm{ng} / \mathrm{ml}$ ) from J anuary to May in the $10^{\circ} \mathrm{C}$-LDN group (Fig. 2). I GF-I levels of the $10^{\circ} \mathrm{C}$-LD 16:8 group increased abruptly after 1 wk of increased day length and remained significantly higher than in the $10^{\circ} \mathrm{C}$-LDN group for $9 \mathrm{wk}$ (mid-February to late mid-April). Increased day length in the ambient temperature-LD 16:8 group did not significantly alter plasma IGF-I relative to the ambient temperatureLDN group. Plasma IGF-I was significantly influenced by time, temperature, photoperiod, and temperaturephotoperiod interaction $(P<0.001)$.

Plasma cortisol levels of the $10^{\circ} \mathrm{C}$-LDN group were low in February $(<10 \mathrm{ng} / \mathrm{ml})$ and then increased in March and remained relatively stable through May (mean 12-25 ng/ml; Fig. 2). Increased day length resulted in significant increases in plasma cortisol after $3 \mathrm{wk}$, and these values were significantly higher than in the $10^{\circ} \mathrm{C}$-LDN group from late February to midMarch. There was also a significant effect of increased day length in the ambient temperature LD 16:8 group, but this was of shorter duration than in the $10^{\circ} \mathrm{C}$ group (significant at $7 \mathrm{wk}$ after increased day length). Both ambient temperature groups had increased plasma cortisol concurrent with increased temperature beginning in late April. Plasma cortisol was significantly influenced by time, temperature, and interaction among time, temperature, and photoperiod $(P<0.001)$.

Plasma $\mathrm{T}_{4}$ levels of the $10^{\circ} \mathrm{C}$-LDN group remained relatively stable throughout the study (mean 5-8 ng/ $\mathrm{ml}$; Fig. 3). Plasma $\mathrm{T}_{4}$ levels were significantly higher after 1 wk of increased day length in the $10^{\circ} \mathrm{C}-\mathrm{LD} 16: 8$ group and were significantly higher than in the $10^{\circ} \mathrm{C}$ LDN group for 5 wk (mid-F ebruary to mid-March). The effect of increased day length at ambient temperature on plasma $\mathrm{T}_{4}$ levels was not detectable until mid-May. Plasma $\mathrm{T}_{4}$ levels in the ambient temperature groups were higher than in the $10^{\circ} \mathrm{C}$ groups in February and increased approximately twofold through the spring. Plasma $\mathrm{T}_{4}$ was significantly influenced by time, temperature, photoperiod, and temperature-photoperiod interaction $(P<0.01)$.

Plasma $\mathrm{T}_{3}$ levels of both $10^{\circ} \mathrm{C}$ groups were low in J anuary, increased in early February, and decreased progressively thereafter ( $\mathrm{Fig}$. 3). Although plasma $\mathrm{T}_{3}$ levels were significantly higher in the $10^{\circ} \mathrm{C}-\mathrm{LD} 16: 8$ group in late F ebruary, this was due to a decrease in the $10^{\circ} \mathrm{C}$-LDN group rather than a change in the $10^{\circ} \mathrm{C}$-LD 16:8 group. Similarly, increased day length had little effect at ambient temperature, with only a slight difference between the LD 16:8 and LDN groups in early
April. Plasma $\mathrm{T}_{3}$ levels were generally higher at $10^{\circ} \mathrm{C}$ than at ambient temperatures, particularly in February. Plasma $T_{3}$ was significantly influenced by time, temperature, photoperiod, and interaction among time, temperature, and photoperiod $(P<0.01)$.

Theratio of $\mathrm{T}_{3}$ to $\mathrm{T}_{4}$ in plasma of the $10^{\circ} \mathrm{C}$-LDN group was low in J anuary, increased in early February, decreased in late February, and then leveled off for the remainder of the study (Fig. 3). A similar pattern was observed in the $10^{\circ} \mathrm{C}-\mathrm{LD} 16: 8$ group, but $\mathrm{T}_{3}: \mathrm{T}_{4}$ ratio was significantly lower in this group from mid-F ebruary to mid-March. The $T_{3}: T_{4}$ ratio was significantly lower in the ambient temperature groups than in the $10^{\circ} \mathrm{C}$ groups at all time points. There was no significant difference in $T_{3}: T_{4}$ ratio between the photoperiod treatments at ambient temperatures at any time. Plasma $T_{3}: T_{4}$ ratio was significantly influenced by time and temperature $(P<0.001)$.

There were significant positive correlations between gill $\mathrm{Na}^{+}-\mathrm{K}^{+}$-ATPase activity and plasma $\mathrm{GH}\left(\mathrm{r}^{2}=0.63\right.$; Fig. 4), I GF-I ( $\left.r^{2}=0.42\right)$, and cortisol $\left(r^{2}=0.31\right)$, but not with plasma $T_{4}, T_{3}$, or $T_{3}: T_{4}$ ratio. A best subsets regression model of hormones on gill $\mathrm{Na}^{+}-\mathrm{K}^{+}$-ATPase activity included plasma GH and cortisol $\left(r^{2}=0.71\right)$, but not IGF-I, $\mathrm{T}_{4}$, or $\mathrm{T}_{3}$.

There were significant negative correlations between condition factor and plasma GH $\left(r^{2}=0.67\right)$, IGF-I $\left(r^{2}=\right.$ $0.35)$, and $T_{3}\left(r^{2}=0.20\right)$, but not with plasma cortisol, $\mathrm{T}_{4}$, or $\mathrm{T}_{3}: \mathrm{T}_{4}$ ratio. A best subsets regression model of hormones on condition factor included plasma GH and $\mathrm{T}_{3}\left(\mathrm{r}^{2}=0.78\right)$, but not IGF-I, cortisol, or $\mathrm{T}_{4}$.

Plasma GH was positively correlated with IGF-I $\left(r^{2}=0.62\right.$; Fig. 4), but not with any other endocrine parameter. Plasma cortisol was positively correlated with plasma $T_{4}\left(r^{2}=0.24\right)$ and negatively correlated with plasma $T_{3}: T_{4}$ ratio $\left(r^{2}=0.28\right)$. Plasma $T_{4}$ was negatively correlated with plasma $T_{3}\left(r^{2}=0.16\right)$. There were no other significant correlations among the endocrine parameters.

\section{DISCUSSION}

In the present study, smolting of Atlantic salmon as measured by increased gill $\mathrm{Na}^{+}-\mathrm{K}^{+}$-ATPase and decreased condition factor was advanced by increased day length when fish were held at elevated temperatures $\left(10^{\circ} \mathrm{C}\right)$ through the winter, but not when fish were held at cooler, ambient temperatures of $2^{\circ} \mathrm{C}$. These findings indicate that low temperature prevents artificial increases in day length from advancing the parr-smolt transformation in Atlantic salmon. At elevated winter temperatures $\left(10^{\circ} \mathrm{C}\right)$, increased day length resulted in higher levels of plasma GH, IGF-I, $\mathrm{T}_{4}$, and cortisol, whereas plasma $T_{3}$ levels were not affected. At ambient winter temperatures $\left(2^{\circ} \mathrm{C}\right)$, increased day length resulted in increases in plasma GH, IGF-I, $\mathrm{T}_{4}$, and cortisol that are much smaller, are of shorter duration, and occur later than at $10^{\circ} \mathrm{C}$. Our results indicate that low temperature limits the ability of photoperiod to advance the physiological aspects of smolting and that this limitation occurs through a delayed and dampened 

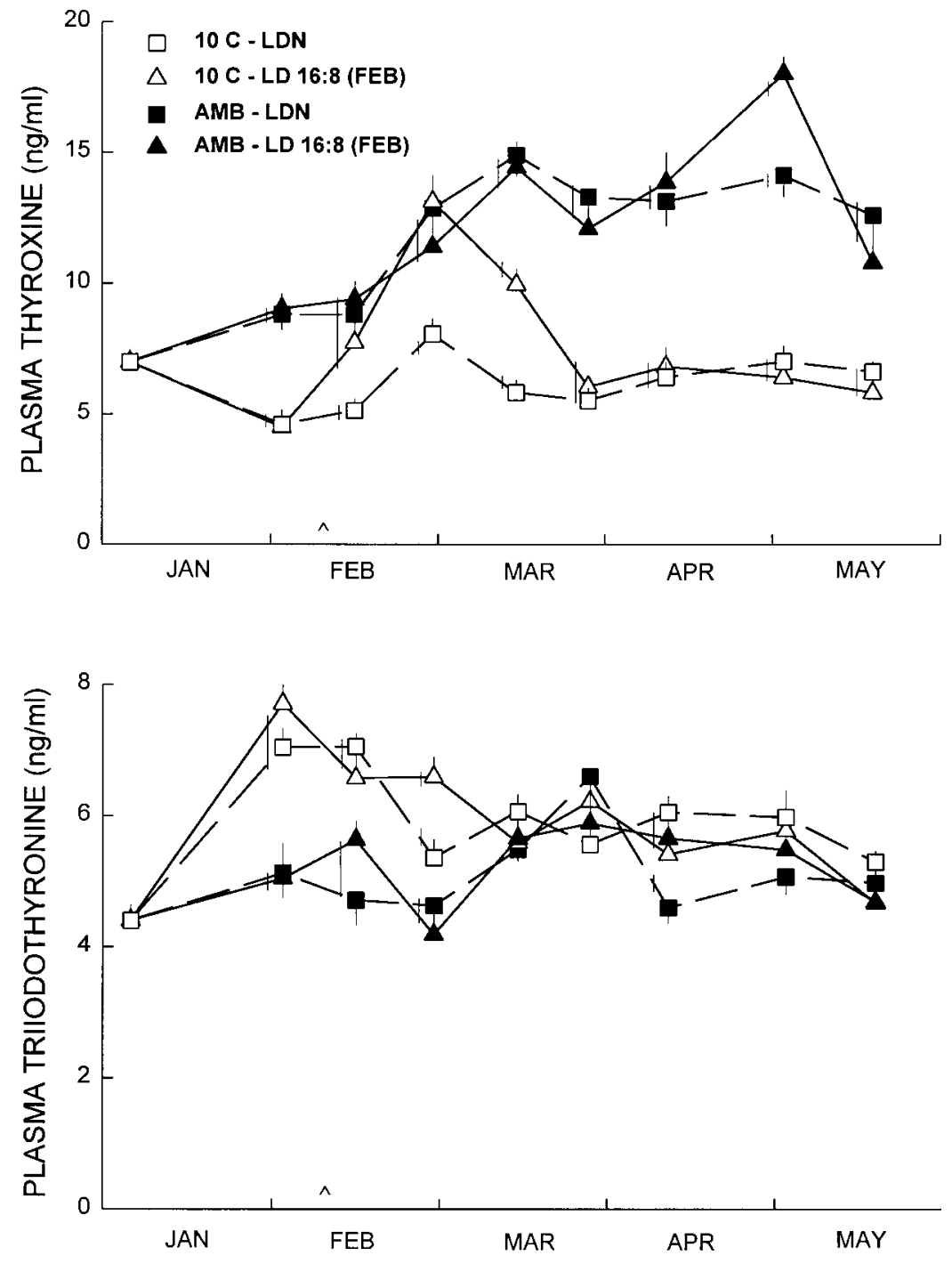

Fig. 3. Plasma thyroxine $\left(T_{4}\right)$, triiodothyronine $\left(T_{3}\right)$, and $T_{3}: T_{4}$ ratio in juvenile Atlantic salmon subjected to photoperiod and temperature treatments (see Fig. 1). Values are means \pm SE $(n=12)$. Increased day length in LD 16:8 groups occurred on 8 February 8 (caret). Vertical lines unconnected to other lines indicate a significant difference from other groups at that time; points without vertical lines are not significantly different from one another ( $P=0.05$, Kruskal-Wallis test).

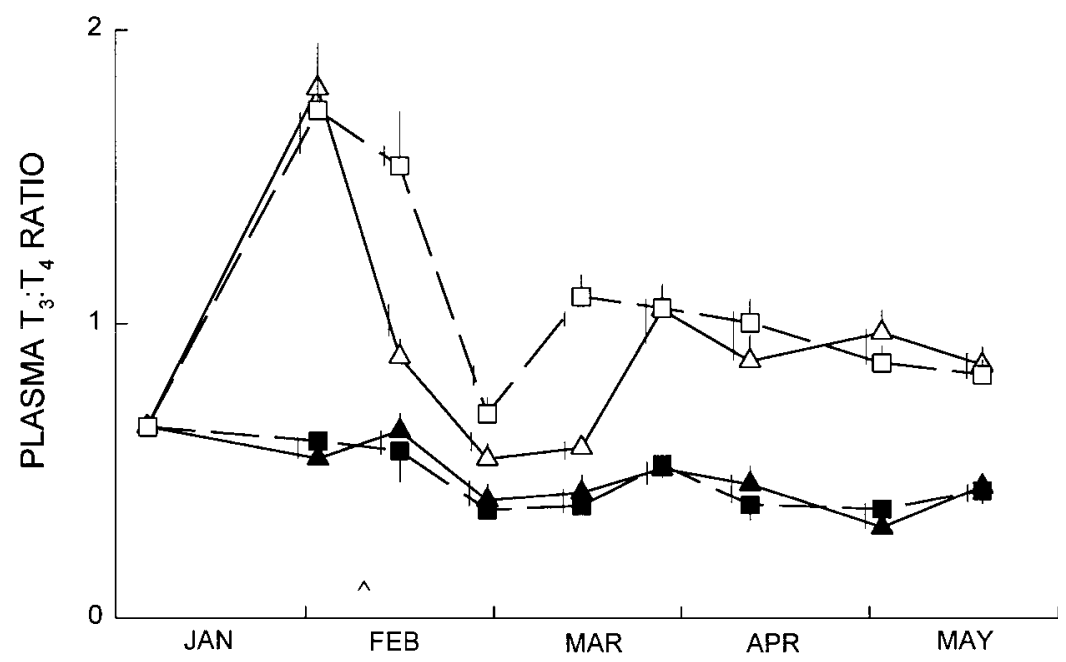

response of the endocrine system to increased day length at low temperature.

Previous work has demonstrated a strong effect of day length on smolt devel opment in Atlantic and Pacific salmon (4, 9, 15, 35, 43, 44). Photoperiod exerts a similar effect on teleostean circannual rhythms, such as reproduction $(7,40)$. Exposure to short days for 6 wk is an apparent requirement for increased day length to 

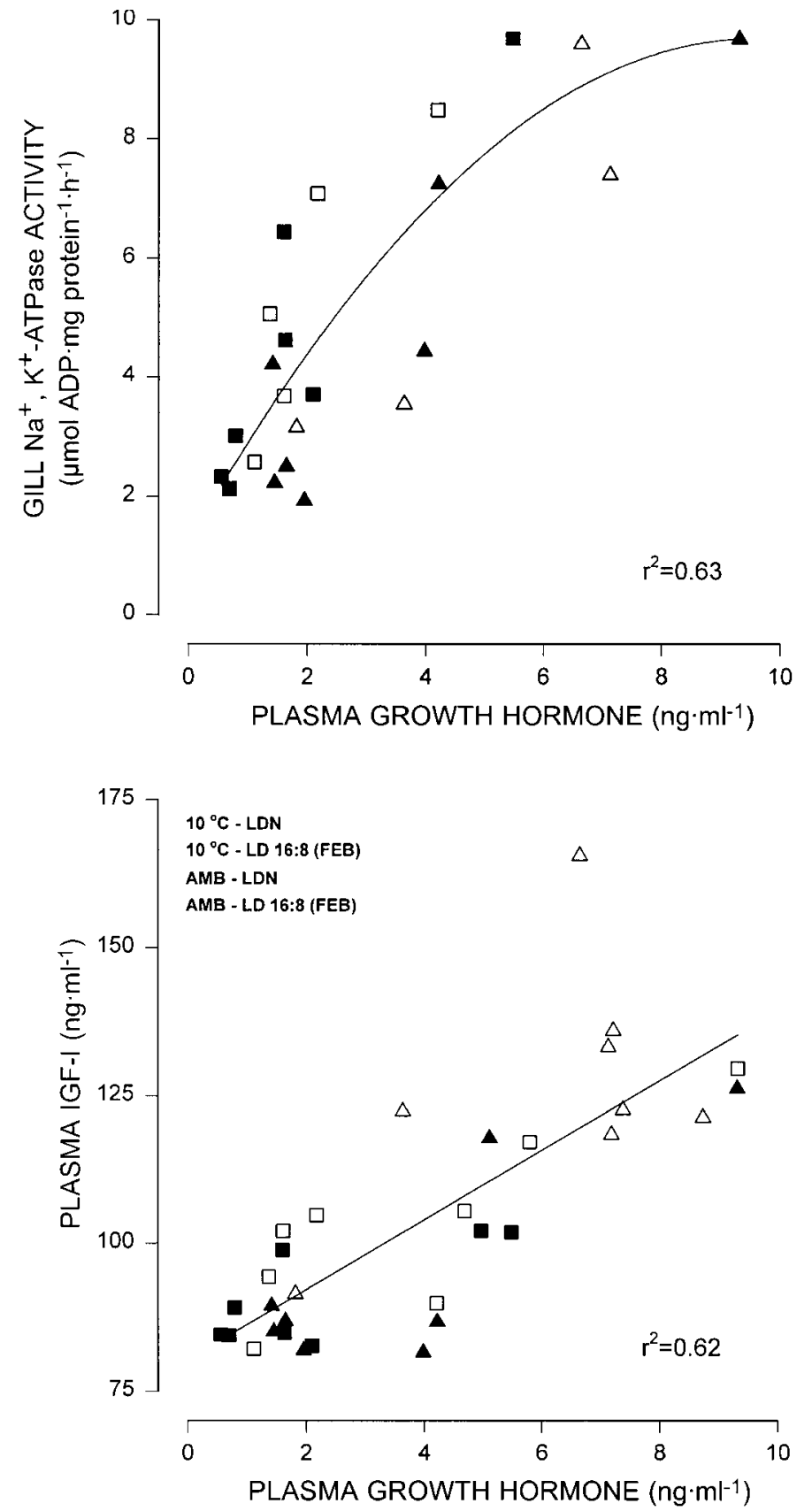

Fig. 4. Regression of plasma growth hormone with gill $\mathrm{Na}^{+}-\mathrm{K}^{+}$ ATPase activity and IGF-I. Values are means $(n=12)$ for each time point from each of the photoperiod and temperature treatments. Analysis of covariance with treatment as a covariable indicated that treatment was not significant $(P>0.1)$ but increased $r^{2}$ to 0.75 and 0.69 for gill $\mathrm{Na}^{+}-\mathrm{K}^{+}-$ATPase activity and I GF - I, respectively. Symbols as in Figs. 1-3.

advance smolting (48). Increases in salinity tolerance and gill $\mathrm{Na}^{+}-\mathrm{K}^{+}-$ATPase under a short day photoperiod provide limited evidence for a circannual rhythm of smolting $(15,31)$. All previous studies that have examined the influence of photoperiod on smolting have used el evated temperatures $\left(>7^{\circ} \mathrm{C}\right)$, higher than those normally seen in temperate North America in winter. To our knowledge, the present study is the first to demonstrate a limiting effect of low temperature on theability of photoperiod to alter a seasonal physiological response.

Thereare several possible mechanisms through which temperature may interact with and limit the endocrine response to increased day length. Temperature influences the rate at which physiological changes, such as enzyme synthesis, occur in response to environmental and endocrine signals (22). However, the strong relationship between circulating hormone levels, particularly $\mathrm{GH}$, and physiological response in all treatments suggests that this mechanism is operating at the level of the pituitary or above, and not at the physiological target organs. One possible mechanism is a direct metabolic $\left(\mathrm{Q}_{10}\right)$ effect of temperature on hormone synthesis and release. In this case, the photoperiodic stimulation received by endocrine organs would be the same, but the capacity to respond is lower at low temperatures. This possible direct effect of temperature seems be most applicable to $\mathrm{GH}$, where plasma levels increased in both temperature groups after day length increased (with a more substantial increase at $10^{\circ} \mathrm{C}$ ) and increased under ambient conditions when temperature increased in late April. Other endocrine systems, however, did not respond to temperature in the same manner. Enzyme systems involved in hormone degradation will have lower activity at low temperature, and binding of hormones to their receptors may also be affected.

It is also possible that pineal and circannual time keeping are affected by temperature. Several authors have suggested that the pineal transduces photic and thermal information $(1,16,50)$. Although temperature compensation occurs in mammalian circadian rhythms, this compensation is not complete, and temperature may have significant effects on phase changes (41). I ncomplete temperature compensation in a circannual rhythm could explain the present results. Several teleosts have demonstrated circadian oscillation of the pineal melatonin cycle, but the rainbow trout, a close relative of Atlantic salmon, has no circadian melatonin cycle and responds directly to the light-dark cycle (16). Temperature has a direct effect on the trout pineal: higher temperatures increase the amplitude of the melatonin cycle and increase the sensitivity of the pineal to light. If the daily melatonin rhythms are involved in transducing information to the hypothalamic-pituitary cycle, this influence of temperature on the pineal could explain the present results. However, in contrast to the situation in mammals, the importance of melatonin rhythms in controlling circannual rhythms in fish is not well established (27). The intensity and duration of hypothalamic signals may also be affected by temperature, although to our knowledge this has not been investigated in fish.

Analysis of previous studies on Atlantic sal mon reared at different temperatures indicates that a change in rearing temperature from 2 to $10^{\circ} \mathrm{C}$ can advance smolting by up to 4 wk (36). These findings are consistent with the present study in which the peak of gill $\mathrm{Na}^{+}-\mathrm{K}^{+}$-ATPase activity was delayed by $4 \mathrm{wk}$ in fish in LDN and ambient temperature compared with fish at 
LDN and $10^{\circ} \mathrm{C}$. Atlantic salmon reared under continuous light and three increasing temperature regimens do not develop normal smolting in spring (46), indicating that temperature alone is not a sufficient cue for smolting. It is possible that the effect of temperature within a given photoperiod also worked through a temperature-photoperiod interaction, such that the stimulatory effect of increased day length in both photoperiod treatments was lower at low temperature. If this were the case, one would expect the ambient temperature groups to have the same endocrine profiles until temperatures began to increase, after which the LD 16:8 group would have higher levels. This pattern was not seen in any of the hormones examined in this study. Alternatively, temperature can have a more direct effect on circulating hormones, similar to the $\mathrm{Q}_{10}$ effect discussed above. This is seen to some degree in all the hormones measured in this study, inasmuch as plasma GH, IGF-I, cortisol, and $\mathrm{T}_{4}$ were generally lower in each photoperiod at cooler temperatures. Furthermore, plasma GH, I GF-I, and especially cortisol increased in the ambient temperature groups coincident with increasing temperature in late April and May. These results suggest that temperature may act on the GH-IGF-I and interrenal axes directly and through a temperature-photoperiod interaction. These effects differ slightly but significantly for each hormone. Combinations of photoperiod and temperature will therefore have a complex effect on endocrine patterns and the timing of smolt devel opment.

Decreased condition factor is associated with the increased metabolic rate, lipid utilization, and growth rate that accompany smolting (18). Condition factor had decreased within 1 wk of increased day length at $10^{\circ} \mathrm{C}$, indicating a rapid response of growth and metabolism to photoperiod changes at el evated temperatures. In contrast, increases in gill $\mathrm{Na}^{+}-\mathrm{K}^{+}$-ATPase activity were not seen in the 1st wk after increased day length at $10^{\circ} \mathrm{C}$ but were seen after $3 \mathrm{wk}$. This period of response is consistent with the known time course of action of hormones on gill $\mathrm{Na}^{+}-\mathrm{K}^{+}$-ATPase, generally requiring 7-14 days for significant increases to occur (29). $\mathrm{Na}^{+}-\mathrm{K}^{+}$-ATPase mRNA in gills of brown trout can increase within $48 \mathrm{~h}$ of salinity transfer or hormone treatment (25). Salinity tolerance also has a relatively rapid response to exogenous GH and IGF-I, increasing within 2 days of treatment (33). The long response time necessary for increased gill $\mathrm{Na}^{+}-\mathrm{K}^{+}-$ATPase activity may be due to the proliferation and differentiation of chloride (salt secretory) cells, increased synthesis of enzymesubunits, and their transport to the basolateral membrane that comprise this physiological response $(26,53)$.

The present study provides evidence for the central importance of GH in smolt development. Of the endocrine factors examined, plasma GH had the earliest and most robust response to increased day length at $10^{\circ} \mathrm{C}$ and the most severely dampened response at low temperature. Plasma GH also had the greatest correlation with condition factor and gill $\mathrm{Na}^{+}-\mathrm{K}^{+}$-ATPase activity. Although smolting is clearly a multihormonal process, GH may be the primary endocrine mediator of environmental information for smolt development (3, 11) and may coordinateand facilitate theaction of other hormones involved in smolting. As in other vertebrates, $\mathrm{GH}$ is in teleost fish the major secretagogue for liver and locally produced IGF-I (13), which has been shown to carry out at least some of the osmoregulatory actions of GH (33). There is a clear interaction between $\mathrm{GH}$ and cortisol in stimulating salinity tolerance, gill chloride cells, and gill $\mathrm{Na}^{+}-\mathrm{K}^{+}$-ATPase activity $(24,30)$. ACTH induced cortisol secretion in salmon can be potentiated by $\mathrm{GH}$ in vivo and in vitro (52). GH may also promote responsiveness to cortisol by increasing the number of gill cortisol receptors (45). There are also clear links between the osmoregulatory actions of $\mathrm{GH}$ and thyroid hormones in salmonids (21), although the nature of this interaction is unclear.

High spring levels of plasma I GF-I and hepatic I GF-I mRNA have been found in Atlantic and coho salmon smolts $(2,14,23,42)$. In the present study, plasma IGF-I increased in all groups between March and May. Increased day length in the $10^{\circ} \mathrm{C}$ group resulted in substantial and sustained increases in plasma IGF-I, providing the first evidence that photoperiod regulates circulating levels of IGF-I in fish. Temperature had a less pronounced effect on plasma IGF-I. There were only occasional differences between the $10^{\circ} \mathrm{C}$ and ambient temperature groups under LDN and only a slight increase in plasma IGF -I when temperature rose in the ambient temperature group in May. Plasma IGF-I of smolting chinook salmon is also higher when fish are reared at warmer temperatures (2). We have shown a strong correlation between plasma GH and IGF-I in Atlantic salmon, supporting the importance of $\mathrm{GH}$ as the major releasing factor for circulating IGF-I. This correspondence between circulating IGF-I and GH is not perfect, inasmuch as large increases in plasma GH late in the study resulted in only slight changes in IGF-I. In addition, temperature seemed to be more important in regulating GH than I GF-I. It seems likely that other endocrine factors are involved in regulating plasma IGF-I. Recent studies have shown that, as in mammals, insulin can affect IGF-I production and release (37, 39).

Plasma $\mathrm{T}_{4}$ levels increased after increased day length at $10^{\circ} \mathrm{C}$, but not at $2^{\circ} \mathrm{C}$. In contrast, plasma $\mathrm{T}_{3}$ was not significantly affected by photoperiod treatment. Although the number of studies is low, there has not been a consistent effect of photoperiod in regulating thyroid hormones in salmonids $(19,35,38)$. GH has been shown to increase $\mathrm{T}_{4}: \mathrm{T}_{3}$ conversion in some teleosts (10), but plasma $T_{3}$ was decreasing when $\mathrm{GH}$ was at high levels in all the groups, and there was no correlation between plasma $\mathrm{GH}$ and $\mathrm{T}_{3}: \mathrm{T}_{4}$ ratio. Given that $\mathrm{a}$ plasma $\mathrm{T}_{4}$ "surge" is characteristic of Pacific and Atlantic salmon smolts $(12,31,35)$, the absence of changes in plasma $\mathrm{T}_{4}$ in the $10^{\circ} \mathrm{C}$-LDN group is somewhat surprising. Temperature, rather than photoperiod, seemed to be more important in regulating thyroid hormones in the present study. Plasma $T_{3}: T_{4}$ ratio was lower in fish reared at ambient temperature, suggesting that 
deiodinase activity may be lower at cold temperatures. However, plasma $\mathrm{T}_{3}: \mathrm{T}_{4}$ ratio was higher in the ambient temperature group throughout the study, even when temperature was similar in the two groups in May. Although temperature had a clear effect on thyroid hormones, the relationship is complex and not direct.

Changes in plasma GH, IGF-I, cortisol, and thyroid hormones observed in this study are consistent with their interactive effects in mediating environmentally induced changes in smolt development. The ultimate biological role of the environmental cues governing the parr-smolt transformation is to time completion of smolting to coincide with river and ocean conditions that are optimal for smolt survival. These optimal conditions are not only related to season, so that the fish enter the ocean in early summer when near-coast food supplies have increased, but are also related to temperature. In the river, increased temperatures often signify increased water flows, which in turn make downstream migration faster and diminish predation risk in rivers and estuaries. Food availability also usually increases with increased river temperatures. Thus our results which show that low temperature limits the capacity of photoperiod to advance smolting by delaying changes in the endocrine system are consistent with the biological advantages for the organism to delay smolting and migration during unusually cold springs or in higher latitudes.

\section{Perspectives}

Many poikilothermic animals use photoperiod to time seasonal events such as migration and reproduction. In salmon and other species, the interaction of temperature and photoperiod may be adaptive for the optimal timing of seasonal responses. In other animals, however, such as those that must respond before increased spring temperatures, an interaction of temperature and photoperiod may not be adaptive. It will thus be of interest to determine whether temperature modulation of the photoperiod response is a common feature of "cold-blooded" vertebrates or whether some animals possess compensatory mechanisms for the influence of temperature on the response to changing day length.

We thank the White River National Fish Hatchery, US Fish and Wildlife Service, for providing fish and J udith Carey, Michael O'Dea, and Gunilla E riksson for excellent technical assistance. Eric Bittman made many hel pful comments in review of the manuscript.

This study was financed in part by a grant from the Swedish Council for Forestry and Agricultural Research to B. T. Björnsson.

Address for reprint requests and other correspondence: S. D. McCormick, Conte Anadromous Fish Research Center, Biological Resources Division, USGS, PO Box 796, Turners Falls, MA 01376.

Received 17 May 1999; accepted in final form 17 November 1999.

\section{REFERENCES}

1. Barrett RK and Takahashi J S. Temperature compensation and temperature entrainment of the chick pineal cell circadian clock. J Neurosci 15: 5681-5692, 1999.

2. Beckman BR, Larsen DA, Moriyama S, Leepawlak B, and Dickhoff WW. Insulin-like growth factor-I and environmental modulation of growth during smoltification of spring chinook salmon (Oncorhynchus tshawytscha). Gen Comp Endocrinol 109: 325-335, 1998.

3. Bjornsson BT. The biology of salmon growth hormone: from daylight to dominance. Fish Physiol Biochem 17: 9-24, 1997.

4. Björnsson BT, Stefansson SO, and Hansen T. Photoperiod regulation of plasma growth hormone levels during parr-smolt transformation of Atlantic salmon: implications for hypoosmoregulatory ability and growth. Gen Comp Endocrinol 100: 73-82, 1995.

5. Bjornsson BT, Taranger GL, Hansen T, Stefansson SO, and Haux C. The interrelation between photoperiod, growth hormone, and sexual maturation of adult Atlantic salmon (Salmo salar). Gen Comp Endocrinol 93: 70-81, 1994.

6. Boujard T and Leatherland J F. Circadian pattern of hepatosomatic index, liver glycogen and lipid content, plasma nonesterified fatty acid, glucose, $T_{3}, T_{4}$, growth hormone and cortisol concentrations in Oncorhynchus mykiss held under different photoperiod regimes and fed using demand-feeders. Fish Physiol Biochem 10: 111-122, 1992.

7. Cagnacci A and Volpe A. Influence of melatonin and photoperiod on animal and human reproduction. J Endocrinol Invest 19: 382-411, 1996.

8. Carey J B and McCormick SD. Atlantic salmon smolts are more responsive to an acute handling and confinement stress than parr. Aquaculture 168: 237-253, 1998.

9. Clarke WC, Shelbourn JE, and Brett J R. Growth and adaptation to seawater in underyearling sockeye (Oncorhynchus nerka) and coho (Oncorhynchus kisutch) salmon subjected to regimes of constant or changing temperatureand daylength. Can J Zool 56: 2413-2421, 1978.

10. De Luze A, Leloup J , Papkoff H, Kikuyama S, and Kawauchi H. Effects of vertebrate prolactins and growth hormones on thyroxine 5'-monodeiodination in the eel (Anguilla anguilla): a potential bioassay for growth hormone. Gen Comp Endocrinol 73: 186- 193, 1989.

11. Dickhoff WW, Beckman BR, Larsen DA, Duan C, and Moriyama S. The role of growth in endocrine regulation of salmon smoltification. Fish Physiol Biochem 17: 231-236, 1997.

12. Dickhoff WW, Darling DS, and Gorbman A. Thyroid function during smoltification of salmonid fish. Gunma Symp Endocrinol 19: 45-61, 1983.

13. Duan C, Duguay SJ , Swanson P, Dickhoff WW, and Plisetskaya E. Tissue-specific expression of insulin-like growth factor I messenger ribonucleic acids in salmonids: developmental, hormonal, and nutritional regulation. In: Perspectives in ComparativeEndocrinol ogy, edited by Davey KG, Peter RE, and Tobe SS. Ottawa, ON, Canada: Natl. Res. Council Canada, 1994, p. 365- 372.

14. Duan CM, Plisetskaya E M, and Dickhoff WW. Expression of insulin-like growth factor I in normally and abnormally developing coho salmon (Oncorhynchus kisutch). Endocrinology 136: 446-452, 1995.

15. Duston J and Saunders RL. The entrainment role of photope riod on hypoosmoregulatory and growth-related aspects of smolting in Atlantic salmon (Salmo salar). Can J Zool 68: 707-715, 1990.

16. Ekstrom $\mathbf{P}$ and Meissl H. The pineal organ of teleost fishes. Rev Fish Biol Fisheries 7: 199-284, 1997.

17. Gwinner E. Circannual systems. In: Biological Rhythms, edited by Aschoff J . New York: Plenum, 1981, p. 391-410.

18. Hoar WS. The physiology of smolting salmonids. In: Fish Physiology, edited by Hoar WS and Randall D. New York: Academic, 1988, vol. XIB, p. 275-343.

19. Hoffnagle TL and Fivizzani AJ. Effect of three hatchery lighting schemes on indices of smoltification in chinook salmon. Prog Fish Culturist 60: 179- 191, 1998.

20. Leatherland J F. Environmental physiology of the teleostean thyroid gland: a review. Environ Biol Fishes 7: 83-110, 1982.

21. Leloup J and Lebel J M. Triiodothyronine is necessary for the action of growth hormone in acclimation to seawater of brown (Salmo trutta) and rainbow trout (Oncorhynchus mykiss). Fish Physiol Biochem 11: 165-173, 1993.

22. Lin J J and Somero GN. Temperature-dependent changes in expression of thermostabile and thermolabile isozymes of cyto- 
solic malate dehydrogenase in the eurythermal goby fish Gillichthys mirabilis. Physiol Zool 68: 114-128, 1998.

23. Lindahl KI, Sara V, Fridberg G, and Nishimiya T. The presence of somatomedin in the Baltic salmon, Salmo salar, with special referenceto smoltification. Aquaculture 45: 177-183, 1985.

24. Madsen SS. Enhanced hypoosmoregulatory response to growth hormone after cortisol treatment in immature rainbow trout, Salmo gairdneri. Fish Physiol Biochem 8: 271-279, 1990.

25. Madsen SS, J ensen MK, Nohr J , and Kristiansen K. Expression of $\mathrm{Na}^{+}-\mathrm{K}^{+}$-ATPase in the brown trout, Salmo trutta: in vivo modulation by hormones and seawater. AmJ Physiol Regulatory Integrative Comp Physiol 269: R1339-R1345, 1995.

26. Marshall WS and Bryson SE. Transport mechanisms of seawater tel eost chloride cells-an inclusive model of a multifunctional cell. Comp Biochem Physiol A Physiol 119: 97-106, 1998.

27. Mayer I, Bornestaf C, and Borg B. Melatonin in nonmammalian vertebrates: physiological role in reproduction? Comp Biochem Physiol A Physiol 118: 515-531, 1997.

28. McCormick SD. Methods for nonlethal gill biopsy and measure ment of $\mathrm{Na}^{+}, \mathrm{K}^{+}$-ATPase activity. Can J Fish Aquat Sci 50: 656-658, 1993

29. McCormick SD. Hormonal control of gill $\mathrm{Na}^{+}, \mathrm{K}^{+}$-ATPase and chloride cell function. In: Fish Physiology. I onoregulation: CelluIar and Molecular Approaches, edited by Wood CM and Shuttle worth TJ . New York: Academic, 1995, vol. XIV, p. 285-315.

30. McCormick SD. Effects of growth hormone and insulin-like growth factor I on salinity tolerance and gill $\mathrm{Na}^{+}, \mathrm{K}^{+}$-ATPase in Atlantic salmon (Salmo salar): interactions with cortisol. Gen Comp Endocrinol 101: 3-11, 1996.

31. McCormick SD, Björnsson BT, Sheridan M, Eilertson C, Carey J B, and O'Dea M. Increased daylength stimulates plasma growth hormone and gill $\mathrm{Na}^{+}, \mathrm{K}^{+}$-ATPase in Atlantic salmon (Salmo salar). J Comp Physiol [A] 165: 245-254, 1995.

32. McCormick SD and Naiman RJ . Osmoregulation in the brook trout, Salvelinus fontinalis. I. Diel, photoperiod and growth related physiological changes in freshwater. Comp Biochem Physiol A Physiol 79: 7-16, 1984.

33. McCormick SD, Sakamoto T, Hasegawa S, and Hirano T. Osmoregulatory action of insulin-like growth factor I in rainbow trout (Oncorhynchus mykiss). J Endocrinol 130: 87-92, 1991.

34. McCormick SD and Saunders RL. Preparatory physiological adaptations for marinelife in salmonids: osmoregulation, growth and metabolism. Am Fish Soc Symp 1: 211-229, 1987.

35. McCormick SD, Saunders RL, Henderson EB, and Harmon PR. Photoperiod control of parr-smolt transformation in Atlantic salmon (Salmo salar): changes in salinity tolerance, gill $\mathrm{Na}^{+}, \mathrm{K}^{+}$-ATPase activity and plasma thyroid hormones. Can J Fish Aquat Sci 45: 1462-1468, 1987.

36. McCormick SD, Shrimpton J M, and Zydlewski J D. Temperature effects on osmoregulatory physiology of juvenile anadromous fish. In: Global Warming: I mplications for Freshwater and MarineFish, edited by Wood CM and McDonald DG. Cambridge: Cambridge University Press, 1996, p. 279-301.

37. Moriyama S, Swanson P, Nishii M, Takahashi A, Kawauchi H, Dickhoff WW, and Plisetskaya EM. Development of a homologous radioimmunoassay for coho salmon insulin-like growth factor-I. Gen Comp Endocrinol 96: 149- 161, 1994.
38. Okumoto N, I kuta K, Aida K, Hanyu I, and Hirano T. Effects of photoperiod on smolting and hormonal secretion in masu salmon, Oncorhynchus kisutch. Aquaculture 82: 6376-6376, 1989.

39. Plisetskaya EM and Duan CM. Insulin CM and insulin-like growth factor I in coho salmon Oncorhynchus kisutch injected with streptozotocin. Am J Physiol Regulatory Integrative Comp Physiol 267: R1408-R1412, 1994.

40. Randall CF, Bromage NR, Duston J , and Symes J . Photope riod-induced phase-shifts of the endogenous clock controlling reproduction in the rainbow trout: a circannual phase-response curve. J Reprod Fertil 112: 399-405, 1998.

41. Ruby NF and Heller HC. Temperature sensitivity of the suprachiasmatic nucleus of ground squirrels and rats in vitro. J Biol Rhythms 11: 126-136, 1996.

42. Sakamoto T, Hirano T, Madsen SS, Nishioka RS, and Bern HA. Insulin-like growth factor I gene expression during parrsmolt transformation of coho salmon. Zool Sci 12: 249-252, 1995.

43. Saunders R L and Henderson E B. Influence of photoperiod on smolt devel opment and growth of Atlantic salmon (Sal mo salar). J Fish Res Board Can 27: 1295-1311, 1970.

44. Saunders RL, Henderson E B, and Harmon PR. Effects of photoperiod on juvenile growth and smolting of Atlantic salmon and subsequent survival and growth in sea cages. Aquaculture 45: 55- 66, 1985.

45. Shrimpton J M, Devlin RH, Mclean E, Byatt J C, Donaldson EM, and Randall DJ . Increases in gill corticosteroid receptor abundance and saltwater tolerance in juvenile coho salmon (Oncorhynchus kisutch) treated with growth hormoneand placental lactogen. Gen Comp Endocrinol 98: 1- 15, 1995.

46. Sigholt T, Asgard T, and Staurnes M. Timing of parr-smolt transformation in Atlantic salmon (Salmo salar): effects of changes in temperature and photoperiod. Aquaculture 160: 129144, 1998.

47. Takahashi J S and Zatz M. Regulation of circadian rhythmicity. Science217: 1104-1111, 1982.

48. Thorarensen $\mathbf{H}$ and Clarke WC. Smoltification induced by a "skel eton" photoperiod in underyearling coho salmon (Oncorhynchus kisutch). Fish Physiol Biochem 6: 11-18, 1989.

49. Thorpe J E, McConway MG, Miles MS, and Muir J S. Diel and seasonal changes in resting plasma cortisol levels in juvenile Atlantic salmon, Salmo salar L. Gen Comp Endocrinol 65: 19-22, 1987

50. Underwood $\mathbf{H}$. The pineal and melatonin: regulators of circadian function in lower vertebrates. Experientia 46: 120-128, 1990.

51. Wedemeyer GA, Saunders RL, and Clarke WC. Environmental factors affecting smoltification and early marine survival of anadromous salmonids. Mar Fish Rev 42: 1-14, 1980.

52. Young G. Enhanced response of the interrenal of coho salmon (Oncorhynchus kisutch) to ACTH after growth hormone treatment in vivo and in vitro. Gen Comp Endocrinol 71: 85- 92, 1988

53. Zadunaisky J A. Chloride cells and osmoregulation. Kidney Int 49: 1563-1567, 1996 